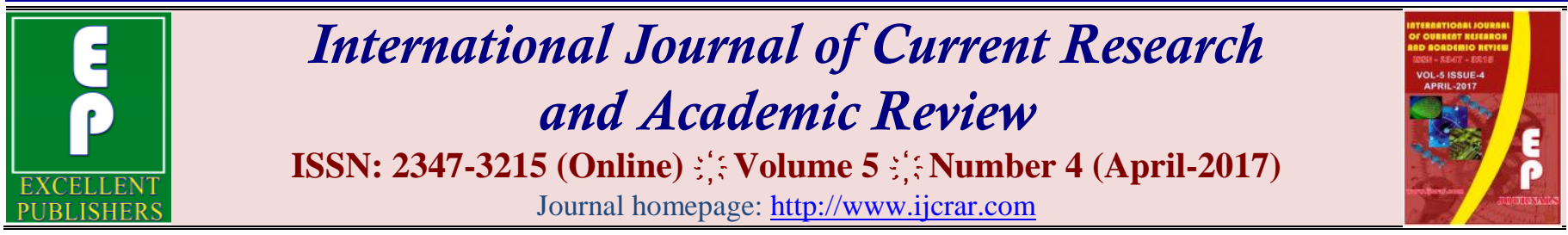

doi: https://doi.org/10.20546/ijcrar.2017.504.008

\title{
Efficacy of the Aqueous Extract of the Seeds Capsules of Ricinus communis on the Infestations of Shoot and Fruit Borer Leucinodes orbonalis Guenee (Lepidoptera: Pyralidae), Pest of Eggplant
}

\author{
Adagba Obodji ${ }^{1 *}$, Kevin Christian Djè Tano ${ }^{2}$, Louis Roi Nondenot Aboua ${ }^{1}$, Christian Landry \\ Ossey $^{1}$ and Nadège Marina Apie Assi ${ }^{1}$
}

\begin{abstract}
${ }^{I}$ University Félix Houphouët Boigny, Abidjan-Cocody, UFR-Biosciences, Laboratory of Zoology and Animale Biology, 22 PO Box 582 Abidjan 22, Côte d'Ivoire

${ }^{2}$ University Jean Lorougnon Guédé of Daloa, UFR-Agroforestry, Côte d'Ivoire
\end{abstract}

*Corresponding author: obodjiada@yahoo.fr

\begin{abstract}
This study was carried out from April to November 2014 in Azaguié, located in the south of Côte d'Ivoire. It consisted in testing the effect of the aqueous extract of the seeds capsules of Ricinus communis on the infestations of shoot and fruit borer Leucinodes orbonalis, pest of eggplant. Five treatments corresponding to five concentrations of aqueous extract of the seeds capsules of $R$. communis were compared to treatment with the chemical insecticide. The lowest infestation percentages and the highest percentages reduction of shoots and fruits infestation were obtained with aqueous extract seeds capsules of the $R$. communis at concentrations of 50 and $60 \mathrm{~g} / 1$ compared to those obtained with the chemical insecticide. The aqueous extract of the seeds capsules of $R$. communis (50 and $60 \mathrm{~g} / 1$ ) also allowed to record the highest total and marketable fruit yields This extract was therefore more effective than the chemical insecticide.
\end{abstract}

\section{Article Info}

Accepted: 04 April 2017

Available Online: 20 April 2017

Keywords

Leucinodes orbonalis, eggplant, aqueous extract, seeds capsules,

$R$. communis, chemical insecticide.

\section{Introduction}

Eggplant is a vegetable of high consumption in tropical Africa and especially in Côte d'Ivoire (Lester et al., 1990; DSDI, 2005). It is grown for its fruits and leaves that are used in various culinary techniques in Africa (Daunay et al., 1997; N'Tamon, 2007). In Côte d'Ivoire, as part of the ivorian food self-sufficiency policy, great importance has been given to vegetable crops including eggplant, which are allocated large areas. However the eggplant crop is confronted with the harmful action of several insect pests, the most formidable of which is Leucinodes orbonalis, which cause considerable damage to eggplant mainly by their larvae (Obodji et al., 2015). To combat this pest, it is the chemical control that is commonly employed.

Unfortunately, this method of control based on the use of chemical insecticides has many disadvantages, namely destruction of non-target organisms (pest insect predator, pollinator), environmental pollution (water, air and soil), the accumulation of toxic residues in fruits, thereby harming human health (Pasteur and Poirie, 1991). Because of the adverse effects of chemical insecticides, researches are oriented towards plants with an insecticidal effect for crop protection. Thus, we are 
conducting this study to control infestations of $L$. orbonalis using Ricinus communis plant in south Côte d'Ivoire.

\section{Materials and Methods}

\section{Study site}

The study was carried out at Azaguié (5 ${ }^{\circ} 37$ north latitude; $4^{\circ} 02$ west longitude), a area located in south of Côte d'Ivoire. The sub-equatorial climate of this locality is characterized by four seasons two dry seasons (minor and major seasons) and two rainy seasons (minor and major seasons). The work was carried out at temperatures ranging from 24.7 to $28.3^{\circ} \mathrm{C}$, relative humidity ranging from 81.9 to $89.9 \%$ and rainfall of $1844.49 \mathrm{~mm}$.

\section{Preparation of aqueous extracts}

The capsules of the seeds of $R$. communis were harvested in the locality of Azaguié. These organs were dried in the shade (sheltered from the sun) during three to four weeks. The capsules were then milled in a blender until obtain powder. An amount of $100 \mathrm{~g}$ of powder obtained was diluted in $200 \mathrm{ml}$ of distilled water. The whole (powder + distilled water) was then homogenized in the blender for five minutes. The resulting mixture was then filtered using poplin.

Two other filtrations were made respectively with Whatman paper and with the aid of the hydrophilic cotton placed in a funnel. The product obtained from these three filtrations was put into melam plates and then concentrated by evaporation in an oven set at $50^{\circ} \mathrm{C}$ during 48 hours until a dry residue was obtained. The dry residue obtained made it possible to prepare five concentrations of aqueous extracts $(20 \mathrm{~g} / 1 ; 30 \mathrm{~g} / 1 ; 40 \mathrm{~g}$ / 1; $50 \mathrm{~g} \mathrm{/} \mathrm{1;} 60 \mathrm{~g} \mathrm{/} \mathrm{1)} \mathrm{which} \mathrm{were} \mathrm{used} \mathrm{to} \mathrm{treat} \mathrm{the}$ subplots. For the chemical insecticide called K-Optimal 35 EC containing the active products which are: lambdacyhalothrin $(15 \mathrm{~g} / \mathrm{l})$ and acetamiprid $(20 \mathrm{~g} / \mathrm{l})$, the dose recommended for the treatment of the plants was $4 \mathrm{ml}$ of the product diluted in 1.5 litres of water.

\section{Experimental device and application of treatments}

The variety of eggplant (Solanum aethiopicum) used in this study was N'drowa issia. The experimental device was Fisher block at a three repetition composed of three blocks separated from each other by 2.5 meters. Each block consists of seven (7) elementary plots. In each block, the chemical insecticide was applied to one (1) elementary plot and five (5) elementary plots were received the different concentrations of the aqueous extract of the capsules of seeds of $R$. communis. A control plot was not treated. Two (2) hand-held sprayers with a capacity of one liter were used to perform the treatments. One was used to apply the chemical insecticide and the other sprayer was used to apply the aqueous extract of capsules of the seeds of $R$. communis. The various concentrations were sprayed one after the other. A total of 13 treatments were carried out and those was done at intervals of two weeks from transplanting to the end of the eggplant cycle.

\section{Assessment of the effect of aqueous extracts on the infestations caused by $L$. orbonalis}

To evaluate the efficacy of aqueous extracts at different concentrations $(20 \mathrm{~g} / \mathrm{l} ; 30 \mathrm{~g} / \mathrm{l} ; 40 \mathrm{~g} / \mathrm{l} ; 50 \mathrm{~g} / \mathrm{l} ; 60 \mathrm{~g} / \mathrm{l})$, one week after each treatment, 10 plants were selected randomly per elementary plot and were examined in order to count all the shoots and to identify those that are infested by the $L$. orbonalis larvae. At the fructification stage, in addition to counting the infested shoots, all fruits on the 10 plants selected randomly were harvested to count the infested and uninfested fruits. The fruits were weighed using a scale. The percentages of shoots infestation and percentages reduction of shoots infestation, the percentages of fruits infestation and percentages reduction of fruits infestation, the total and marketable fruits yields were calculated using the following formulas:

$$
\text { Percentage of shoots infestation }=\frac{\text { Number of infested shoots }}{\text { Total number of shoots }} \times 100
$$

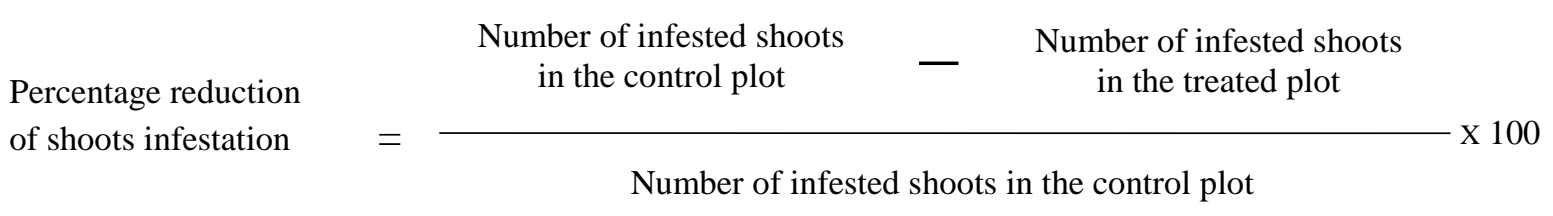




Percentage of fruits infestation $=\frac{\text { Number of infested fruits }}{\text { Total number of fruits }} \times 100$
$\begin{aligned} & \text { Percentage reduction } \\ & \text { of fruits infestation }\end{aligned}=\frac{\begin{array}{c}\text { Number of infested fruits } \\ \text { in the control plot }\end{array}}{\text { Number of infested fruits in the control plot }}$
$\begin{gathered}\text { Number of infested fruits } \\ \text { in the treated plot }\end{gathered}$

Total yield $\left(\mathrm{t} \mathrm{h}^{-1}\right)=\frac{\text { Weight of uninfested fruits }+ \text { Weight of infested fruits }}{\text { Surface where the fruits were harvested }}$

Marketable fruits yield $\left(\mathrm{t} \mathrm{h}^{-1}\right)=\frac{\text { Weight of uninfested fruits }}{\text { Surface where the fruits were harvested }}$

\section{Data analysis}

Data processing was performed using statistica software version 7.1. An analysis of variance (ANOVA) revealed significant differences between the data. The test of Student-Newman Keuls at 5\% was used to classify the means into homogeneous groups.

\section{Results and Discussion}

\section{Effect of aqueous extract of seeds capsules on shoots infestation}

\section{Percentage of shoots infestation}

The percentage of infested shoots on the control plot was $28.08 \pm 1.55 \%$. The chemical insecticide allowed to record an percentage of infested shoots of $5.25 \pm 0.13 \%$. The lowest percentages of shoots infestation were obtained with the aqueous extract of the seeds capsules at concentrations of 50 and $60 \mathrm{~g} / \mathrm{l}$. These infestation percentages were $1.77 \pm 0.19(50 \mathrm{~g} / \mathrm{l})$ and $1.83 \pm 0.2 \%$ (60 g / 1) (Fig.1a). Analysis of variance (ANOVA) followed by the Newman- Keul test revealed significant differences between percentages shoots infestation.

\section{Percentage reduction of shoots infestation}

Percentages reduction of shoots infestation were higher with the aqueous extract of seeds capsules at concentrations of $50 \mathrm{~g} / \mathrm{l}(93.31 \pm 0.80 \%)$ and $60 \mathrm{~g} / \mathrm{l}$ $(93.18 \pm 0.81 \%)$ comparatively to that obtained with the chemical insecticide $(79.85 \pm 1.05 \%)$ (Fig.1b). The analysis of variance (ANOVA) followed by the Newman-Keul test showed significant differences between the percentages of reduction of shoots infestation.

\section{Effect of aqueous extract of seeds capsules on fruits infestation}

\section{Percentage of fruits infestation}

The percentage of infested fruit obtained on the control plot was $29.26 \pm 2.34 \%$. The aqueous extract of the seeds capsules at concentrations of 50 and $60 \mathrm{~g} / \mathrm{l}$ allowed to obtain the lowest percentage of infested fruits which were $2.71 \pm 0.1(50 \mathrm{~g} / \mathrm{l})$ and $2.96 \pm 0.12 \%(60 \mathrm{~g} / \mathrm{l})$ compared to the chemical insecticide which induced a percentage of fruit infestation of $4.85 \pm 0.18 \%$ (Fig.2a). The analysis of variance (ANOVA) followed by the Newman-Keul test revealed significant differences between percentages fruits infestation

\section{Percentage reduction of fruits infestation}

Comparatively to the chemical insecticide which allowed to obtain a percentage reduction of fruits infestation of $73.49 \pm 3.33 \%$, the aqueous extract of the seeds capsules at concentrations of 50 and $60 \mathrm{~g} / \mathrm{l}$ induced the percentages reduction of fruit infestation of $83.84 \pm 1.72$ and $83.46 \pm 1.78 \%$ (Fig.2b). Analysis of variance (ANOVA) followed by the Newman - Keul test showed significant differences between the percentages reduction of fruits infestation. 
Effect of the aqueous extract of the capsules of the seeds on the number, weight of the fruits harvested and yields

\section{Number of infested and uninfested fruits}

The lowest mean numbers of infested fruit were obtained with the aqueous extract of seeds capsules at concentrations at 50 and $60 \mathrm{~g} / 1$ with $0.67 \pm 0.1$ and 0.74 \pm 0.13 fruit per plant compared to the chemical insecticide $(1.02 \pm 0.27$ fruit per plant). The highest mean numbers of uninfested fruits obtained with this extract were $21.79 \pm 1.56(60 \mathrm{~g} / \mathrm{l})$ and $21.93 \pm 2.1(50$ $\mathrm{g} / \mathrm{l})$ fruits per plant. Analysis of variance (ANOVA) followed by the Newman-Keul test showed significant differences between the numbers of fruits (Table 1).

\section{Weight of infested and uninfested fruits}

The aqueous extract of seeds capsules at concentrations of 50 and $60 \mathrm{~g} / \mathrm{l}$ allowed to obtain the lowest mean weights of infested fruits $(256.67 \pm 14.74$ and $262.38 \pm$ $12.51 \mathrm{~g})$ and the highest mean weights of uninfested fruits $(8089.48 \pm 180.33$ and $8166.67 \pm 188.65 \mathrm{~g})$ compared to those obtained by chemical insecticide. Analysis of variance (ANOVA) followed by the
Newman - Keul test revealed significant differences between the fruits numbers (Table 1).

\section{Total and marketable fruits yields}

The highest total and marketable fruits yields were recorded with the aqueous extract of seeds capsules at concentrations of 50 and $60 \mathrm{~g} / \mathrm{l}$ compared to the chemical insecticide. These total yields were $21.18 \pm 0.48 \mathrm{t} \mathrm{h}^{-1}(60$ $\mathrm{g} / \mathrm{l})$ and $21.41 \pm 0.49 \mathrm{t} \mathrm{ha}^{-1}(50 \mathrm{~g} / \mathrm{l})$ and the marketable fruits yields were $19.98 \pm 0.45 \mathrm{t} \mathrm{h}^{-1}(60 \mathrm{~g} / 1)$ and $20.37 \pm$ $0.48 \mathrm{t} \mathrm{h}^{-1}(50 \mathrm{~g} / 1)$. Analysis of variance (ANOVA) followed by the Newman- Keul test indicated significant differences between yields (Table 1).

The aqueous extract of the seeds capsules of $R$. communis at concentrations of 50 and $60 \mathrm{~g} / \mathrm{l}$ allowed to obtain a lower percentage of shoots infestation compared to those induced by the chemical insecticide. It has effectively reduced shoot infestation of $L$. orbonalis. This shows that this aqueous extract (50 and $60 \mathrm{~g} /$ ) was more effective in controlling the infestation of $L$. orbonalis compared to the chemical insecticide. Similar results of efficacy of the aqueous extract seeds capsules of the $R$. communis had been obtained by Tano et al., (2012) which reported higher mortality rates of Coelaenomenodera lameensis adults with this extract.

Table.1 Numbers of fruits, weights of fruits harvested and yields

\begin{tabular}{|c|c|c|c|c|c|c|}
\hline \multirow{2}{*}{$\begin{array}{l}\text { Concentrations } \\
\text { of the aqueous } \\
\text { extract }(\mathrm{g} / \mathrm{l})\end{array}$} & \multicolumn{2}{|c|}{$\begin{array}{l}\text { Average number of fruits } \\
\text { per plant }\end{array}$} & \multicolumn{2}{|c|}{$\begin{array}{c}\text { Average weight of fruits } \\
\text { harvested }(\mathrm{g})\end{array}$} & \multicolumn{2}{|c|}{ Yields $\left(\mathrm{t} \mathrm{h}^{-1}\right)$} \\
\hline & infested & Uninfested & infested & uninfested & total & marketable fruits \\
\hline 20 & $2.35 \pm 1.07^{\mathrm{b}}$ & $17.09 \pm 1.2^{\mathrm{d}}$ & $902.38 \pm 44.38^{\mathrm{b}}$ & $6342.86 \pm 229.34^{\mathrm{d}}$ & $18.11 \pm 0.67^{\mathrm{c}}$ & $15.86 \pm 0.57^{\mathrm{c}}$ \\
\hline 30 & $1.82 \pm 0.59^{c}$ & $19.54 \pm 1.1^{\mathrm{c}}$ & $756.67 \pm 48.35^{\mathrm{c}}$ & $7266.67 \pm 182.49^{c}$ & $19.67 \pm 0.41 \mathrm{~b}$ & $18.17 \pm 0.46^{b}$ \\
\hline 40 & $1.25 \pm 0.18^{\mathrm{d}}$ & $20.22 \pm 1.83^{b}$ & $390.48 \pm 30.79^{\mathrm{d}}$ & $7433.33 \pm 132.62^{b}$ & $20.06 \pm 0.48^{a b}$ & $18.58 \pm 0.33^{b}$ \\
\hline 50 & $0.67 \pm 0.1^{\mathrm{e}}$ & $21.93 \pm 2.1^{\mathrm{a}}$ & $256.67 \pm 14.74^{\mathrm{e}}$ & $8166.67 \pm 188.65^{a}$ & $21.41 \pm 0.49^{\mathrm{a}}$ & $20.37 \pm 0.48^{\mathrm{a}}$ \\
\hline 60 & $0.74 \pm 0.13^{\mathrm{e}}$ & $21.79 \pm 1.56^{\mathrm{a}}$ & $262.38 \pm 12.51^{\mathrm{e}}$ & $8089.48 \pm 180.33^{\mathrm{a}}$ & $21.18 \pm 0.48^{\mathrm{a}}$ & $19.98 \pm 0.45^{\mathrm{ab}}$ \\
\hline $\begin{array}{l}\text { Chemical } \\
\text { insecticide }\end{array}$ & $1.02 \pm 0.27^{\mathrm{d}}$ & $20.58 \pm 1.02^{b}$ & $349.52 \pm 17.18^{\mathrm{d}}$ & $7409.05 \pm 285.44^{b}$ & $20.50 \pm 0.49^{a b}$ & $18.82 \pm 0.39^{b}$ \\
\hline Control & $5.05 \pm 1.32^{\mathrm{a}}$ & $11.02 \pm 1.13^{\mathrm{e}}$ & $1890.95 \pm 233.72^{\mathrm{a}}$ & $4080.95 \pm 149.86^{\mathrm{e}}$ & $14.93 \pm 0.83^{\mathrm{d}}$ & $10.20 \pm 0.37^{\mathrm{d}}$ \\
\hline
\end{tabular}


Fig.1 Percentage of shoots infestation (a) and percentage reduction of shoots infestation (b)
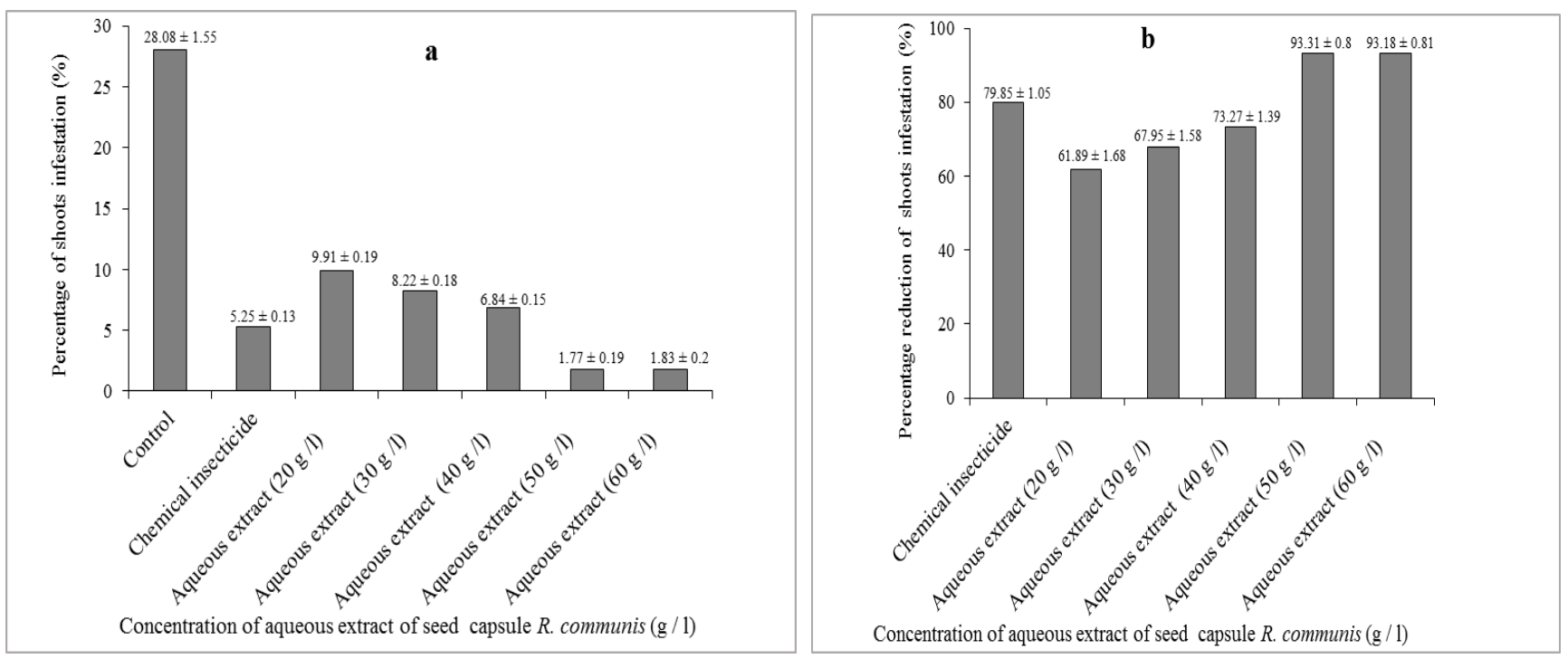

Fig.2 Percentage of fruits infestation (a) and percentage reduction of fruits infestation (b)

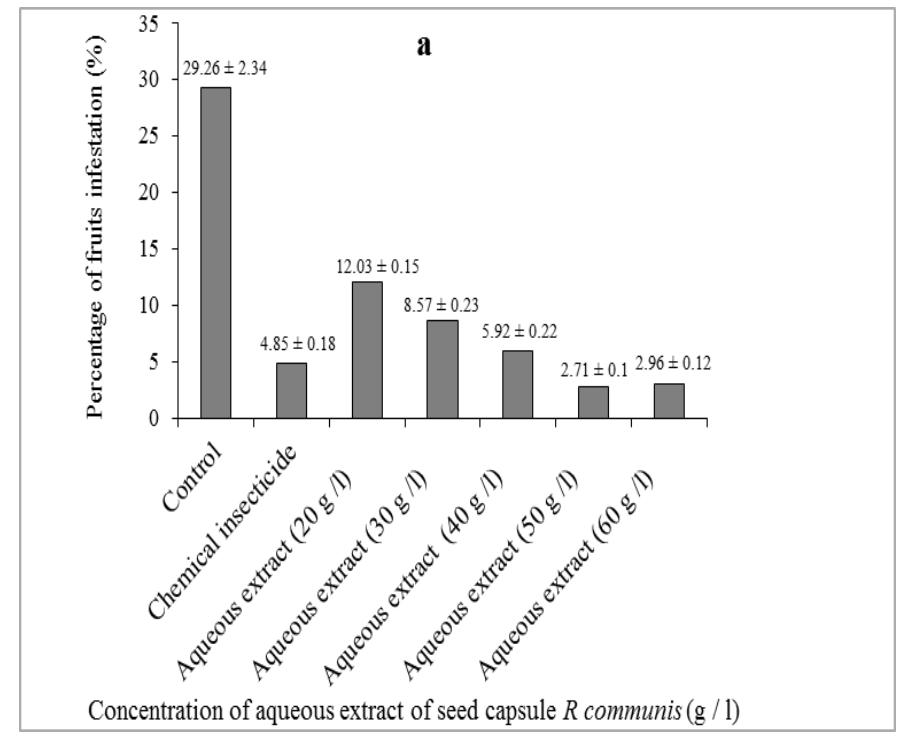

Several authors have reported the effectiveness of the aqueous extract seeds and leaves of $R$. communis in the management against insect pests. Thus Singh and Kaur (2012) mentioned a toxicity of the aqueous extract of R.communis on Musca domestica, Elimam et al., (2009) reported an effectiveness of the aqueous extract of $R$. communis on mosquitoes Anopheles arabiensis and Culex quinquefasciatus in Sudan. Pacheco et al., (2012) also demonstrated remarkable efficacy of alcohol extracts of the leaves and seeds of $R$. communis on the beetle Scyphophorus acupunctatus. A similar study carried out by owusu, 2009 in Ghana revealed that the aqueous extract of Annona muricata permitted to record

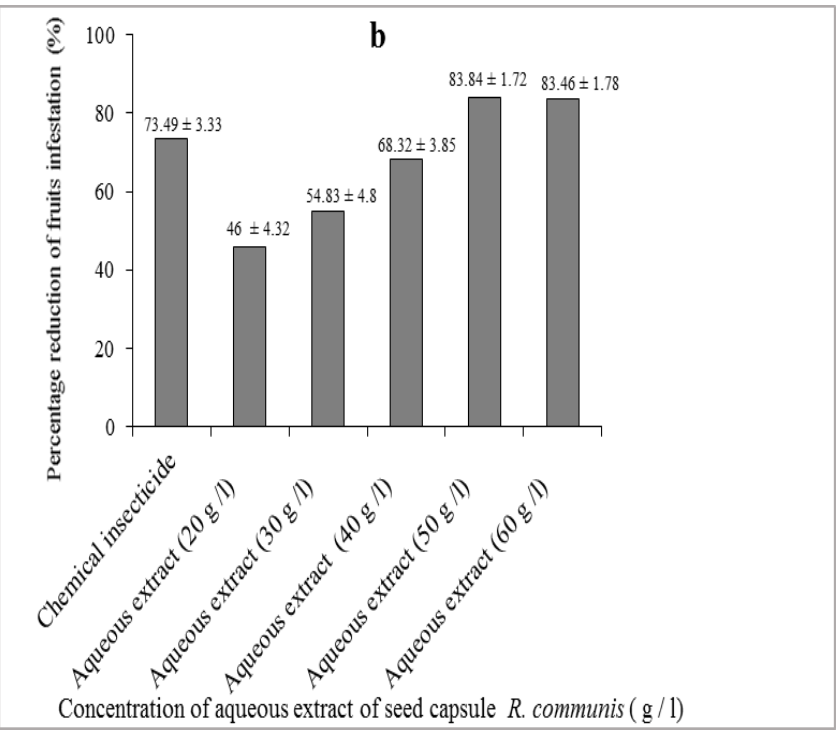

lower percentage of shoots infestation induced by $L$. orbonalis larvae. The aqueous extract of seeds capsules of $R$. communis at concentrations of 50 and $60 \mathrm{~g} / 1$ also allowed to record lower percentages of fruits infestation and a higher percentage of infestation reduction compared to the chemical insecticide. The effectiveness of the aqueous extract of seeds capsules of $R$. communis could be explained by two hypotheses. The first hypothesis is that this extract would have had an ovicidal effect on L. orbonalis. After spraying the aqueous extract, the eggs that would have been laid by the females on the leaves, flower buds or the fruit calyx, as reported by Taley et al., (1984) and Alpuerto (1994) 
would have been destroyed by this extract. According to Alzouma and Boubacar (1987), the ovicidal effect of products of vegetable origin would occur before hatching of the first instar larva. This would be linked to the chemical composition of the various aqueous extracts of plant species. The effectiveness of the aqueous extract of seeds capsules of $R$. communis is due to the ricin contained in the capsules enveloping the seeds and which is a very toxic substance for insects (Burgess et al., 1988; Déthiollaz, 2003; Olsnes, 2004). The second hypothesis would be that the aqueous extract would have repulsive effect on females of $L$. orbonalis. These extracts after application, would have repelled the females of $L$. orbonalis thus preventing a large number of female to lay on the eggplant plants. Results on the repellent effect of aqueous extract of leaves of $R$. communis were obtained by Elimam et al., (2009) who reported that this extract had a remarkable repellent effect on two mosquito species that were Anopheles arabiensis and Culex quinquefasciatus. Other studies on the use of plant extracts to control infestation of $L$. orbonalis have been carried out by several authors. Thus, Chitra et al., (1993) observed, after spraying, aqueous extract leaves of Azadirachta indica, percentage of fruits infestation of 0.1 $\%$ against $69.55 \%$ for the control. Dutta et al., (2011) also reported a significant reduction of percentage of fruits infestation with extract of $A$. indica. Ghatak et al., (2009) also reported a reduction of percentage of fruits infestation with aqueous extract leaves.of Annona squamosa The results showed that the yields (total and marketable fruits) were higher with the aqueous extract of seeds capsules of $R$. communis at concentrations of 50 and $60 \mathrm{~g} / \mathrm{l}$ compared to those obtained with the chemical insecticide. These higher total and marketable fruits yields obtained with the aqueous extract of seeds capsules of $R$. communis would be justified by the fact that the extract would have allowed the plants to be less attacked, to grow well, to have a good health status and to be more productive. Similar results have been reported by Ashadul et al., (2014) and Mondedji et al., (2014). Indeed, Mondedji et al., (2014), in their study, they obtained the highest marketable cabbage yields on plots treated with the hydroethanol extract of leaves of $A$. indica.

\section{Conclusion}

The aqueous extract of the seeds capsules of $R$. communis at concentrations of 50 and $60 \mathrm{~g} / 1$ reduced significantly shoots and fruits infestation caused by the larvae of $L$. orbonalis. This aqueous extract was also allowed to record the highest total and marketable fruits yields. It was therefore more effective than chemical insecticide. In order to preserve human health and the environment, the aqueous extract of capsules of the seeds of $R$. communis could be used as an alternative to the abuse of insecticides for to control $L$. orbonalis infestations.

\section{References}

Alpuerto, A.B. 1994. Ecological studies and management of brinjal fruit and shoot borer, Leucinodes orbonalis Guenee. Indian J. Agri. Sci., 52(6): 391- 395.

Alzouma, I., Boubacar, I. 1987. Effet des feuilles vertes de Boscia senegalensis (Capparidacée) sur la biologie de $B$. atrolineatus et $C$. maculatus (Coleoptera: Bruchidae) ravageurs des graines du niébé. Colloque Int sur "Les légumineuses alimentaires en Afrique", 19-22, Niamey, Niger, pp 288-295.

Ashadul, M.I., Hussain, M.A., Shapla, S.A., Mehraj, H., Jamal, U.A.F.M. 2014. Plant Extract for the Management of Brinjal Shoot and Fruit Borer (Leucinodes orbonalis Guenee. American Eurasian J. Agri. Environ. Sci., 14(12): 1409-1414.

Burgess, E.P.J., Koha, E.M.W.T., Hutchins, R.F.N., Douglas, L. 1988. Toxicity of leaves from the castor oil plant, Ricinus communis L. (Euphorbiaceae), to adult grass grub, Costelytra zealandica (White) (Coleoptera: Scarabaeidae). N. Z. J. Agri. Res., 16: 63-66.

Chitra, K.C., Rao, K.P., Nagaiah, K. 1993. Field evaluation of certain plant products in the control of brinjal pest complex. Indian J. Entomol., 55(3): 237-240.

Daunay, M.C., Lester, R.N., Ano, G. 1997. Les aubergines cultivées. In: Charrier, A., acquot, M., Hamon, S. \& Nicolas, D. (Editors). L'Amélioration des plantes tropicales. Co-edition CIRADORSTOM, Montpellier, France, pp 83-107.

Déthiollaz, S. 2003. La Ricine: une arme biologique. Protéine à la Une, 8: 1- 4.

DSDI. 2005. Annuaire des Statistiques Agricoles. Les Séries Stat'Agri. Direction des Statistiques et de la Documentation (DSDI). Ministère d'Etat, Ministère de l'Agriculture, RCI, Abidjan, pp.100.

Dutta, P., Singha A.K., Das, P., Kalita, S. 2011. Management of brinjal fruit and shoot borer, Leucinodes orbonalis in agro-ecological condition of West Tripura. J. Agri. Sci., 1(2): 16-19.

Elimam, A.M., Elmalik, K.H., Ali, F.S. 2009. Larvicidal, adult emergence inhibition and oviposition deterrent 
effects of foliage extract from Ricinus communis L. against Anopheles arabiensis and Culex quinquefasciatus in Sudan, Trop. Biomed., 26(2): 130-139.

Ghatak, S.S., Mondal, S., Vishwakarma, R. 2009. Bioefficacy of botanicals and biopesticides against brinjal shoot and fruit borer, Leucinodes orbonalis Guenee (Pyralidae: Lepidoptera). Indian $J$. Entomol., 71(4): 284-287.

Lester, R.N., Jaeger, P.M.L., Bleijendaal, B.H.M., Bleijendaal, H.P.O., Holloway, H.L.O. 1990. African eggplants, a review of collecting in West Africa. Plant Genetic Res. Newslett., pp 17-26.

Mondedji, A.D., Nyamador, W.S., Amevoin, K., Ketoh, G.K., Glitho, I.A. 2014. Efficacité d'extraits de feuilles de neem Azadirachta indica (Sapindale) sur Plutella xylostella (Lepidoptera: Plutellidae), Hellula undalis (Lepidoptera: Pyralidae) et Lipaphis erysimi (Hemiptera: Aphididae) du chou Brassica oleracea (Brassicaceae) dans une approche « Champ Ecole Paysan » au sud du Togo. Int. J. Biol. Chem. Sci., 8(5): 2286-2295.

N'Tamon, N.G. 2007. Caractérisation agromorphologique de quelques cultivars d'aubergine (solanum ssp) collectés dans diverses zones écologique de Côte d'Ivoire. Mémoire de fin de cycle d'ingenieur de l'IPR / IFRA de Katibougou (Mali), pp 69.

Obodji, A., Aboua, L.R.N., Séri-Kouassi, B.P, Tano, D.K. Ch., Goué, Z.S. 2015. Evaluation of the damage caused by the shoot and fruit borer: Leucinodes orbonalis Guenee (Lepidoptera: Pyralidae) according to the phenological stages of three varieties of eggplant in south of Côte d'Ivoire. Int. Res. J. Biol. Sci., 4(8): 49-55.

Olsnes, S. 2004. The history of ricin, abrin and related toxins. Toxicon., 44: 361-370.

Owusu, O.D. 2011. Effect of crude ethanolic leaf extract of soursop (Annona muricata L) on eggplant shoot and fruit borer (Leucinodes orbonalis Guen.). Master of Science degree in crop protection (Entomology option). Kwame N'krumah University of Science and Technology Kumasi, Ghana, pp 53.

Pacheco, S.C., Villa, A.P., Montes, B.R., Figueroa, B.R., Jiménez, P.A. 2012. Effect of ricinus communis extracts on weight and mortality of scyphophorus acupunctatus (Coleoptera: curculionidae). Int. J. Appl. Sci. Technol., 2(1): 83-94.

Pasteur, N., Poirie, M. 1991. La résistance des insectes aux insecticides. La Recherche, 22(234): 874-882.

Singh, A., Kaur, J. 2016. Toxicity of Leaf Extracts of Ricinus communis L. (Euphorbiaceace) against the third instar larvae of Musca domestica L. (Diptera: Muscidae). American J. BioSci., 4(3-1): 5-10.

Taley, Y.M., Nighut, U.S., Rajurkar, B.S. 1984. Bionomics of brinjal fruit and shoot borer, (Leucinodes orbonalis Guenee). Punjabrao Krishi Vidyapeeth Res. J., 8(1): 29-39.

Tano, D.K.Ch., Aboua, L.R.N., Séri-Kouassi, B.P., Koua, K.H. 2012. Evaluation of the insecticidal activity of aqueous extracts of five plants on Coelaenomenodera lameensis Berti and Mariau (Coleoptera: Chrysomelidae) pest of oil palm (Elaeis guineensis Jacq.). Int. J. Agri. Sci., 2(2): 120-135.

\section{How to cite this article:}

Adagba Obodji, Kevin Christian Djè Tano, Louis Roi Nondenot Aboua, Christian Landry Ossey and Nadège Marina Apie Assi. 2017. Efficacy of the Aqueous Extract of the Seeds Capsules of Ricinus communis on the Infestations of Shoot and Fruit Borer Leucinodes orbonalis Guenee (Lepidoptera: Pyralidae), Pest of Eggplant. Int.J.Curr.Res.Aca.Rev. 5(4), 49-55. doi: https://doi.org/10.20546/ijcrar.2017.504.008 